7. Kadnikova, O., Altynbayeva, G., Kuzmin, S., Toretayev, M., Khabdullina, Z. Ecological Feasibility ofApplying Technology in Recycling Garment and Knitwear Production /Environmental and Climate Technologies, 2019, 23(2), C. 291-309

8. Kadnikova, O., Altynbayeva, G., Kuzmin, S., Aidarkhanov, A., Shaldykova, B.Recycling of production waste as a way to improve environmental conditions/ Energy Procedia, 2018, 147, C. 402-408

9. Gorelikova, G.A. Osnovy sovremennoj pishhevoj biotehnologii: Uchebnoe posobie / Kemerovo: Kemerovskij tehnologicheskij institut pishhevoj promyshlennosti, 2010. - 100 s. (in Russian).

10. Ezdakov, N.V., Sherstobitov V.V., Levickij A.P [i dr.] Primenenie fermentnyh preparatov v kormoproizvodstve Perspektivy primenenija fermentnyh promyshlennyh preparatov v otrasli kormoproizvodstva. - Kiev: Upr. po pechati, 2012. - S. 41-48. ( in Russian).

11. Smirnova, V.D. Othody proizvodstva koncentrirovannyh belkovyh produktov iz soi kak syr'e dlja poluchenija kormovyh dobavok: avtoref. dis. kand. tehn. nauk: 03.01.06 / Rossijskij himiko-tehnologicheskij universitet imeni D.I. Mendeleeva. - M., 2012. - 19 s. (in Russian).

12. Alimova, F.K., Tazetdinova D.I., Tuhbatova R.I Biotehnologija. Promyshlennoe primenenie gribov roda Trichoderma // Uchebnometodicheskoe posobie. - Kazan': UNIPRESS DAS, 2007. - 234 s. (in Russian).

13. Alimova, F.K., Skvorcov E.V., Mel'nikova T.A., [i dr.] Ispol'zovanie Trichoderma v processe pererabotki othodov spirtovogo proizvodstva /, // Vestnik biotehnologii. - 2007. - № 3. - S. 22-26. (in Russian).

14. Gneusheva, I.A. Pavlovskaja N.E., Biotehnologicheskie metody obrabotki rastitel'nogo syr'ja / // «Innovacionnyj potencial molodyh uchenyh APK Orlovskoj oblasti». Sbornik materialov regional'noj nauchno-prakticheskoj konferencii molodyh uchenyh, aspirantov i studentov, posvjashhennoj 35-letiju Orlovskogo gosudarstvennogo agrar-nogo universiteta. - Orel: Izd-vo Orel GAU, 2010. - S. 66-68. (in Russian).

15. Gneusheva, I.A.. Gor'kova I.V., Dedkov V.N., Biotehnologicheskie podhody dlja poluchenija belkovo-uglevodnyh kormovyh dobavok dlja zhivotnovodstva / // Razvitie innovacionnogo potenciala agropromyshlennogo proizvodstva: Materialy Vserossijskoj nauchno-prakticheskoj konferencii 24 nojabrja 2010 goda. - Orel: Izd-vo OrelGAU, 2010. - S. 45-48. (in Russian).

16. Vitavskaja A.V., Kulazhanov K.S., Hasiev H.H. Zhivaja pishha i zernovoj hleb spasut naselenie planety / LAP Lambert Academic Publishing, ISBN 9783659408724, 2013. - 604 c. (in Russian).

17. Sushkova, V.I.,. Vorob'eva G.I., Bezothodnaja konversija rastitel'nogo syr'ja $\mathrm{v}$ biologicheski aktivnye veshhestva / - M.: DeLi print, 2011.- 16 s. (in Russian).

\title{
EFFECTS OF FERMENTATION ON THE DEGREE OF BREAKING UP OF BONE PARTICLES IN MEAT AND BONE PASTE FROM CATTLE BONES
}

\author{
${ }^{1}$ A. KAKIMOV ${ }^{3}$ A.MAYOROV,${ }^{1}$ A.BAIKADAMOVA *, ${ }^{1}$ B.KABDYLZHAR, \\ ${ }^{2} A$. SUYCHINOV, ${ }^{l} \mathrm{Zh}$. YESSIMBEKOV
}

${ }^{1}$ NJSC «Shakarim University of Semey», Kazakhstan, 071412, Semey, Glinka str., 20A

2 «Semey branch Kazakh Research Institute of Processing and Food Industry», Kazakhstan, 071407, Semey, Baitursynova str., 29

${ }^{3}$ Federal State Budgetary Scientific Institution "Federal Altai Scientific Center of Agrobiotechnologies" Russian Federation, 656910, Altai Territory, Barnaul, settlement Scientific town, 35 Corresponding author e-mail:asemgul93@yandex.ru*

Bone processing is an urgent task of rational use of meat industry waste. Disposal of cattle bones can be carried out by different methods. Various methods are used for processing bone raw materials, such as mechanical processing, chemical hydrolysis, ultrasonic processing, etc. Processed meat and bone raw materials in meat and bone paste are chemically exposed to ascorbic acid $\left(0.05 \mathrm{M}, 1 \mathrm{~h}, 25^{\circ} \mathrm{C}\right)$ and pepsin $(\mathrm{pH}$ $2.0, t=10 \ldots 40{ }^{\circ} \mathrm{C}, \tau=1 . .8 \mathrm{~h}$ ). This allows you to reduce the mass of bone particles in meat and bone paste by 70\%. Meat and bone paste subjected to enzyme processing can be used in the technology of meat products.

Keywords: meat and bone paste, pepsin, cattle bones, food safety, ascorbic acid. 


\title{
ІҚМ СУЙЕКТЕРІНЕН ЖАСАЛҒАН ЕТ-СУЙЕК ПАСТАСЫНДАҒЫ СУЙЕК БӨЛШЕКТЕРІНІН БӨЛІНУ ДӘРЕЖЕСІНЕ ФЕРМЕНТТЕУДІҢ ӘСЕРІ
}

\author{
${ }^{1}$ А.К. КАКИМОВ, ${ }^{3}$ А.МАЙОРОВ, ${ }^{1}$ А.М. БАЙКАДАМОВА*,${ }^{1}$ Б.К. КАБДЫЛЖАР, \\ ${ }^{2}$ А.К. СУЙЧИНОВ, ${ }^{1}$ Ж.С. ЕСИМБЕКОВ \\ 1 «Семей қаласының Шәкәрім атындағы университеті» ҚеАҚ, Қазақстан, 071412, \\ Семей қ., Глинка к-сі, 20a \\ ${ }^{2}$ Қазақ тамақ және қайта өндеу өнеркәсібі ғылыми орталығының Семей филиалы, \\ Қазақстан, 071407, Семей қ., Байтұрсынов к-сі, 29 \\ ${ }^{3}$ Федералдық мемлекеттік бюджеттік ғылыми мекеме "Федералдық Алтай \\ агробиотехнологиялар ғылыми орталығы" \\ Ресей Федерациясы, 656910, Алтай өлкесі, Барнаул қ., Научный городок кенті, 35-үй \\ Автор-корреспонденттің электрондық поштасы: asemgul93@yandex.ru*
}

\begin{abstract}
Сүйекті қайта өңдеу ет өнеркәсібінің қалдықтарын ұтымды пайдаланудың өзекті міндеті болып табылады. Ірі қара малдың сүйектерін кәдеге жсарату әртүрлі әдістермен жүзеге асырылуы мүмкін. Сүйек иикізатын өңдеу үшін механикалық өңдеу, химиялық гидролиз, ультрадыбыстық өңдеу және т.б. Өңделген ет-сүйек иикізаты ет-сүйек пастасына аскорбин қышқылы $\left(0,05 \mathrm{~m}, 1 \mathrm{caz,} 25^{\circ} \mathrm{C}\right)$ және пепсин (рН 2,0, $t=10 . . .40^{\circ} \mathrm{C}, \tau=1 . . .8$ сав) химиялық әсер етеді. Бұл ет және сүйек пастасындавы сүйек бөлиектерінің массасын 70\% азайтуга мүмкіндік береді. Ферментті өңдеуге ұиыраван ет жсәне сүйек пастасын ет өнімдері технологиясында қолдануга болады.
\end{abstract}

Негізгі сөздер: ет-сүйек пастасы, пепсин, ІКМ сүйектері, тағам қауіпсіздігі, аскорбин қышқылы.

\section{ВЛИЯНИЕ ФЕРМЕНТАЦИИ НА СТЕПЕНЬ РАСЩЕПЛЕНИЯ КОСТНЫХ ЧАСТИЦ В МЯСОКОСТНОЙ ПАСТЕ ИЗ КОСТЕЙ КРС}

\author{
${ }^{1}$ А.К. КАКИМОВ ${ }^{3}$ А.МАЙОРОВ, ${ }^{l}$ А.М. БАЙКАДАМОВА ${ }^{*},{ }^{1}$ Б.К. КАБДЫЛЖАР, \\ ${ }^{2}$ A.К. СУЙЧИНОВ, ${ }^{1}$ Ж.С. ЕСИМБЕКОВ
}

\footnotetext{
${ }^{1}$ НАО «Университет имени Шакарима города Семей», Казахстан, 071412, г.Семей, ул.Глинки 20А

${ }^{2}$ Семейский филиал Казахский научно-исследовательский институт перерабатывающей и пищевой промышленности, Казахстан, 071407, г. Семей, ул. Байтурсынова, 29

${ }^{3}$ Федеральное государственное бюджетное научное учреждение "Федеральный Алтайский научный центр агробиотехнологий"
}

Российская федерация, 656910, Алтайский край, г. Барнаул, п. Научный городок, д. 35

Электронная почта автора-корреспондента: asemgul93@yandex.ru*

Переработка кости является актуальной задачей рационального использования отходов мясной промышленности. Утилизация костей крупного рогатого скота может осуществляться разными методами. Для переработки костного сырья применяются различные методы, такие как механическая переработка, химический гидролиз, ультразвуковая переработка и др. Переработанное мясокостное сырье в мясокостную пасту подвергается химическому воздействию аскорбиновой кислотой $\left(0,05 M, 1\right.$ ч, $\left.25^{\circ} \mathrm{C}\right)$ и пепсином (pН 2,0, $t=10 . .40^{\circ} \mathrm{C}, \tau=1 . .8$ ч). Это позволяет уменьщить массу костных частиц в мясокостной пасте на 70\%. Мясокостная паста, подверженная ферментной обработке, может быть использована в технологии мясных продуктов.

Ключевые слова: мясокостная паста, пепсин, кости КРС, пищевая безопасность, аскорбиновая кислота.

\section{Introduction}

One of the essential reserves for increasing the output of useful products and increasing production efficiency in the processing industries is the use of low-waste technologies. In the meat industry, this is primarily about the rational use of bone [1]. 
Disposal of cattle bones can be carried out in different ways. Depending on the type of waste, animal bones are processed in the following ways:

1. Bones with a high fat content are subject to preliminary defatting, and then - the production of bone fat from it.

2. Tubular bones are processed by defatting, which results in bone meal with a fat percentage of less than $10 \%$.

3 . Bones from the thoracic, vertebral and sacral regions become the basis for the production of semi-finished meat products. They can also be processed by mechanical deboning [2].

Due to the inherent hardness of cattle bone as a connective tissue, not all grinders provide fine uniform grinding and it is possible to find bone particles in meat and bone paste.

Fermentation and chemical processing technologies are used to dissolve these bone particles. In some foreign works, methods of processing bone tissue are described. There are known method such as ultrasonic pretreatment to promote enzymatic extraction of chicken bone protein [3].

The authors Jun Cao and others proposed a method for acid treatment and extraction of collagen with pepsin from the waste of the skin and bones of the golden pompano, a genus of marine ray-finned fish [4]. Scientists from Indonesia studied the isolation of collagen from goat bone and determined its characteristics using enzymatic hydrolysis by pepsin in various concentrations [5]. Kuderinova N. A. developed a technology for dissolving bone raw materials without residue using a biological product of active curd serum to obtain a food component of paste consistency [6].
Chemical hydrolysis is a method of using acidic materials in the hydrolysis process [7]. Depending on the concentration of the acid used and the hydrolysis temperature, the processing time can vary from 3 to 24 hours. For example, hydrolysis in the presence of sulfuric acid iscarried out for $3 \div 5$ hours at a temperature from plus 100 to $130{ }^{\circ} \mathrm{C}$ and a pressure of $2 \div 3$ atmospheres; in the presence of hydrochloric acid - for 5-24 hours at the boiling point of the solution under low pressure [8].

Under the action of acid, hydrolysis of proteins reaches the maximum level of protein breakdown and excludes the possibility of bacterial contamination of the hydrolyzate, which is especially important in the food industry. However, this method has a drawback - under such severe conditions of hydrolysis, not only the amount of amine nitrogen increases due to the formation of low molecular weight peptides and free amino acids, but also ammonia, which indicates the destruction of the amino acids themselves [9].

Enzymatic hydrolysis is also used, in particular by using pepsin as an active enzyme [10]. Pepsin is a globular protein with a molecular weight of about 34500. A pepsin molecule is a polypeptide chain that consists of 340 amino acids, contains 3 disulfide bonds ($\mathrm{S}-\mathrm{S}-$ ) and phosphoric acid. Pepsin is an endopeptidase, that is, an enzyme that cleaves the central peptide bonds in protein and peptide molecules to form simpler peptides and free amino acids. Pepsin hydrolyzes peptide bonds formed by aromatic amino acids - tyrosine and phenylalanine with the highest rate, however, unlike other proteolytic enzymes - trypsin and chymotrypsin, it does not have strict specificity [11].

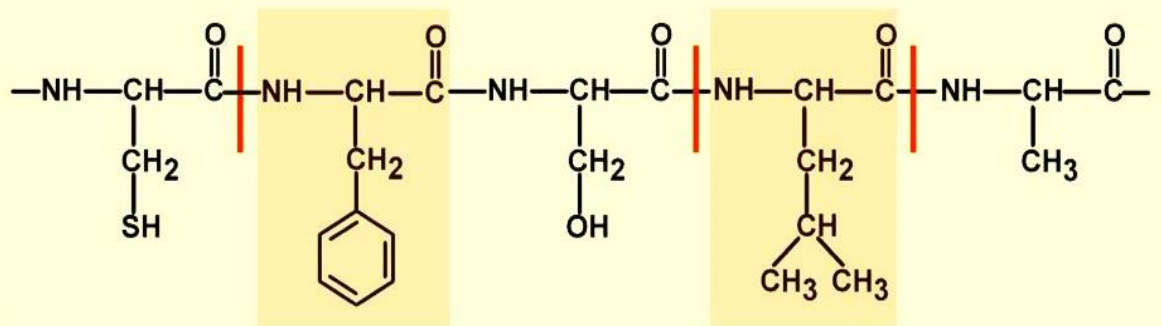

Figure 1. Pepsin formula

Pepsins play a significant role in digestion in mammals, including humans, being an enzyme that performs one of the important stages in the chain of converting food proteins into amino acids.
Pepsin is involved in the digestion of proteins in the gastrointestinal tract. It has a fairly broad specificity in the hydrolysis of proteins and polypeptides. It breaks down almost all proteins of 
plant and animal origin, with the exception of protamines (globular proteins) and keratins [12].

Pepsin is contained in the gastric juice of mammals, birds, reptiles and fish. It is formed mainly in the cells of the glands in the gastric mucosa as an inactive precursor-pepsinogen, which, after cleavage of a peptide consisting of 44 amino acid residues, turns into an active enzyme. Pepsin is most stable at $\mathrm{pH} \mathrm{5}$; at $\mathrm{pH}$ above 6 , it is rapidly and irreversibly inactivated. Optimum catalytic activity of pepsin during protein hydrolysis at $\mathrm{pH} 1.5-2.0$. At the same time, one gram of pepsin in two hours can break down $\sim 50$ $\mathrm{kg}$ of egg albumin, curd $\sim 100,000$ liters of milk, dissolve $\sim 2000$ liters of gelatin $[13,14]$.

Processing of secondary raw materials and waste from the meat processing industry is an urgent task of the food industry. Based on the scientific research of foreign scientists on the breaking up of bone particles of various species of animals and fish, the choice of an enzyme method and preliminary acid treatment of breaking up is justified, since this method is close to the natural environment of the digestive tract of animals and humans.

The purpose of this work is to study the effect of enzyme treatment on the degree of breaking up of bone particles in meat and bone paste from cattle bones.

\section{Materials and research methods}

The objects of the study were meat and bone paste from cattle bones.

Meat and bone raw materials are prefrozen for 60 minutes at a temperature from minus 18 to $20^{\circ} \mathrm{C}$ in freezers. Freezing provides longterm storage at low temperatures. It is aimed for preventing of the development of microbiological processes and a sharp decrease in the rate of enzymatic and physicochemical changes.

The next stage is feeding the frozen raw materials to the hopper of a chopper cutter with a hole diameter of the output mesh of $8 \mathrm{~mm}$. After grinding, the resulting meat and bone mass is frozen to a temperature from minus 18 to $20{ }^{\circ} \mathrm{C}$ and again crushed at the chopper cutter with a hole diameter of the output mesh of 5 $\mathrm{mm}$. Ice water is added to the resulting meat and bone mass in the ratio of raw materials to water 1:0.5 to be frozen for 1 hour.
The resulting meat and bone mass were stirred and crushed again at the chopper cutter with a hole diameter of the output mesh of $3 \mathrm{~mm}$.

The resulting meat and bone mincemeat is frozen for 1 hour to a temperature of $\left((-18){ }^{\circ} \mathrm{C}\right.$ - (-20) $\left.{ }^{\circ} \mathrm{C}\right)$. After freezing, meat and bone mincemeat is sequentially crushed on a microgrinder «Supermasscolloider» with the following gaps between grinding circles: 0.25 $\mathrm{mm}, 0.10 \mathrm{~mm}, 0.02 \mathrm{~mm}$.

The resulting meat and bone paste is stored at a temperature of $2-4{ }^{\circ} \mathrm{C}$ until the next research [15].

The determination of the total chemical composition was carried out by the method of one portion of the test sample. The method consists in sequential determination of moisture, fat, protein and ash content in one sample of the product using a device for determining the moisture and fat content of meat and dairy products by an accelerated method [16]. Energy value was determined by the calculation method.

To determine the granulometric composition and reveal the size of bone particles, the microstructure of bone particles of meat and bone paste was investigated. The bone particle sizes were measured using a "JSM-6390LV" scanning electron microscope (JEOL, Japan) [17].

For the breaking up of bone particles in meat and bone paste, the method of chemical hydrolysis based on preliminary acid treatment of raw materials with organic acid and further action of the enzyme is used.

The experiment is aimed at studying the effect of ascorbic acid and pepsin treatment on the decomposition of the rib bones of cattle in meat and bone paste.

As pepsin, the rennet-beef enzyme VNIIMS SG-50 is produced from calf abomasum and the mucous membrane of the rennet of adult cattle.

The rennet VNIIMS SG-50 is an environmentally friendly product of animal origin, has a high degree of purification and a stable level of activity.

The share of rennet chymosin is $50 \%$, the share of beef pepsin is $50 \%$.

Based on the results of the study of scientific literature, the following research scheme has been developed (Figure 2). 


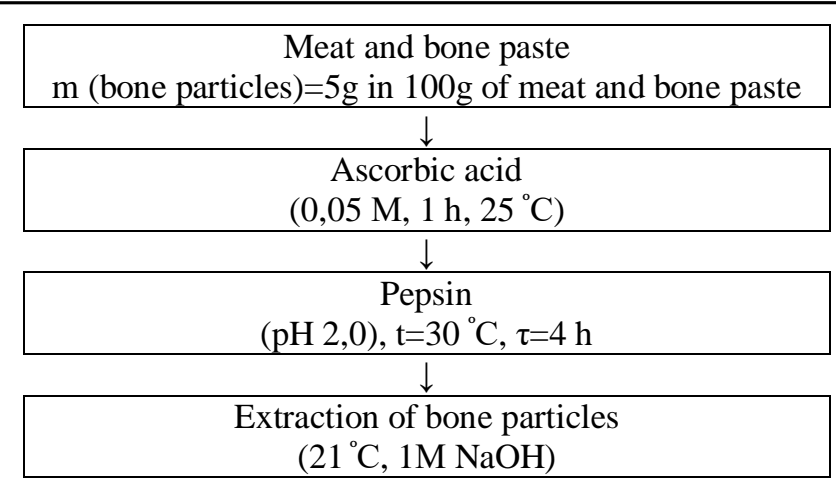

Figure 2. The scheme of the experiment

\section{Results and their discussion}

Physicochemical analysis of meat and bone paste from rib bones of cattle before fermentation indicates a high protein content $12.1 \mathrm{~g} / 100 \mathrm{~g}$ and energy value $-103.2 \mathrm{kcal} / 100 \mathrm{~g}$ (table 1).

Table 1. Physical and chemical analysis of meat and bone paste

\begin{tabular}{|l|c|}
\hline \multicolumn{1}{|c|}{ Name of indicators, units of measurement } & $\begin{array}{c}\text { Meat paste } \\
\text { (rib bones) }\end{array}$ \\
\hline Protein, g/100g & 10,1 \\
\hline Fats, g/100g & 6,7 \\
\hline Carbohydrates, g/100g & 0,5 \\
\hline Mass fraction of moisture content, \% no more & 76,7 \\
\hline Mass fraction of ash content, \% no more & 12 \\
\hline The energy value, kcal/100g & 103,2 \\
\hline
\end{tabular}

Microstructure analysis revealed the presence of bone particles ranging in size from 0.05 to 1 mm (Figure 3).

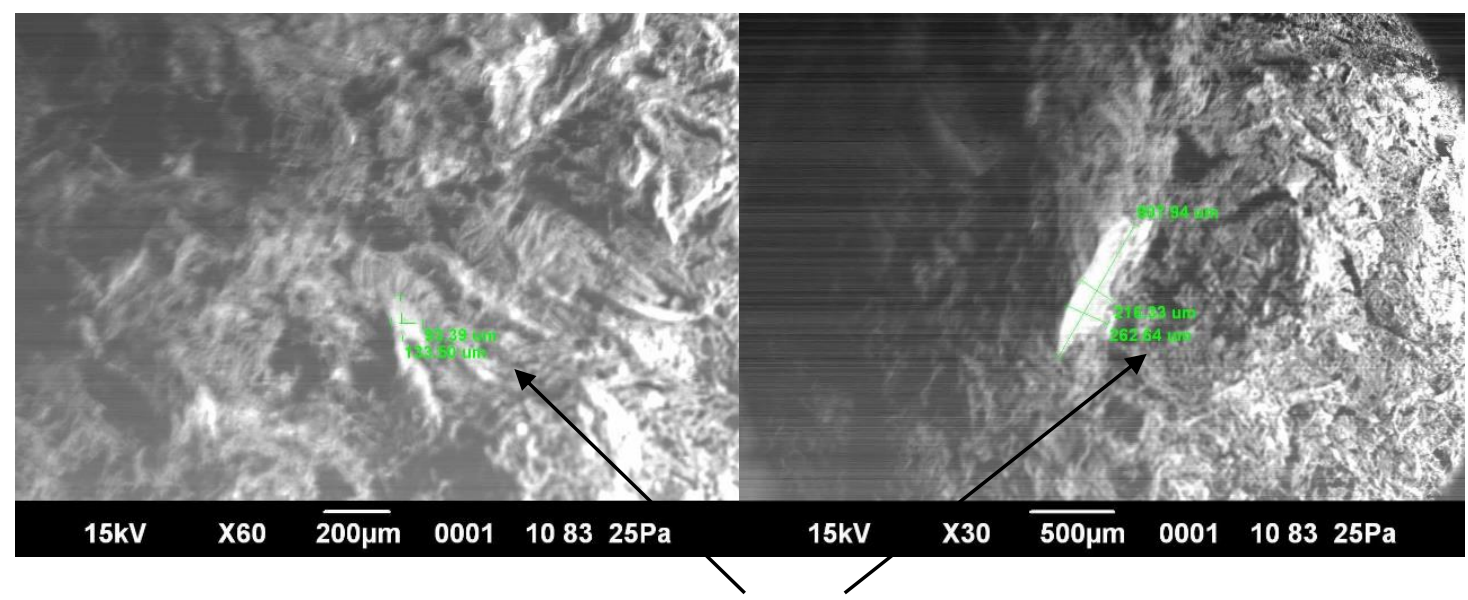

bone particle size

Figure 3. Microstructure of meat and bone paste from cattle bones

The dependence of the breaking up of bone particles of meat and bone paste from rib bones by ascorbic acid and pepsin at the temperature regime was determined, so cleavage occurs most actively at the temperature range from 30 to $40{ }^{\circ} \mathrm{C}$ (table 1 ). If at a temperature of $10{ }^{\circ} \mathrm{C}$ the mass of bone particles is $0.369 \mathrm{~g}$ per $10 \mathrm{~g}$ of meat and bone paste, then at a temperature of 35 ${ }^{\circ} \mathrm{C}$ the mass of bone particles $0.113 \mathrm{~g}$, which is 70 $\%$ less than the mass obtained at 100C. This is due to the optimal temperature of pepsin activity equal to $37-40^{\circ} \mathrm{C}[18]$. 
Table 2. The effect of temperature on the level of splitting of bone particles by calculating their mass

\begin{tabular}{|c|c|}
\hline $\begin{array}{c}\text { Temperature, } \\
{ }^{0} \mathrm{C}\end{array}$ & $\begin{array}{c}\text { The mass of bone particles in } 10 \mathrm{~g} \text { of } \\
\text { raw material after fermentation, } \mathrm{g}\end{array}$ \\
\hline 10 & 0,369 \\
\hline 15 & 0,357 \\
\hline 20 & 0,156 \\
\hline 25 & 0,147 \\
\hline 30 & 0,132 \\
\hline 35 & 0,113 \\
\hline 40 & 0,126 \\
\hline
\end{tabular}

Another factor affecting the effectiveness of the enzyme is the processing time.

So, at an optimal temperature of $35^{\circ} \mathrm{C}$, a significant decrease in the mass of bone particles in the samples under study is observed after 4 hours (figure 4 ):

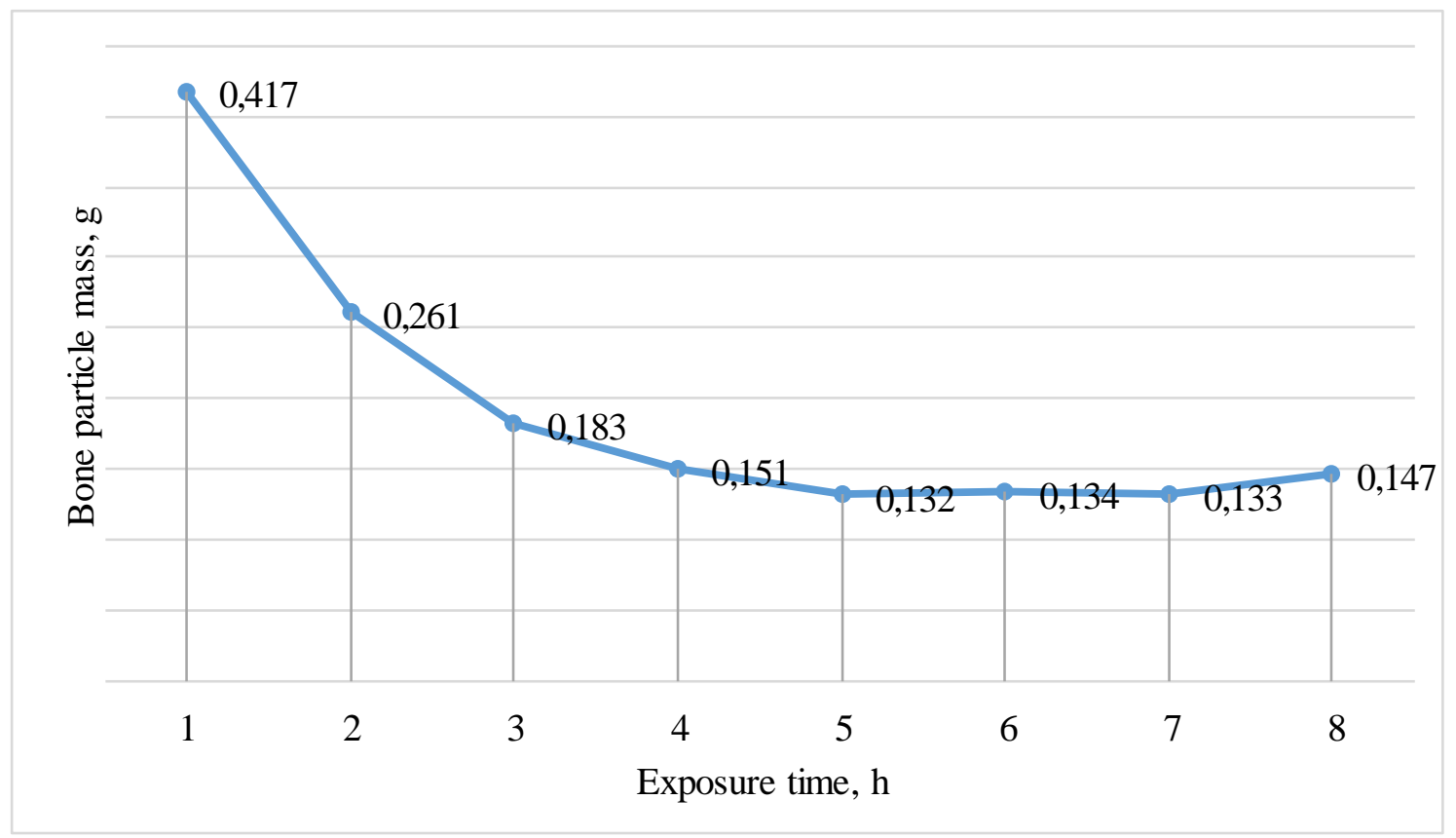

Figure 4. Change in bone mass versus duration of pepsin exposure

The organoleptic assessment of meat and bone paste found that the overall structure of the paste is uniform, the consistency is dense, elastic, without obvious signs of looseness, light brown in color.
Microstructural analysis of meat and bone paste of rib bones after fermentation $(\mathrm{t}=30$ ${ }^{\circ} \mathrm{C}, \tau=4 \mathrm{~h}$ ) showed the absence of bone particles (Figure

5).

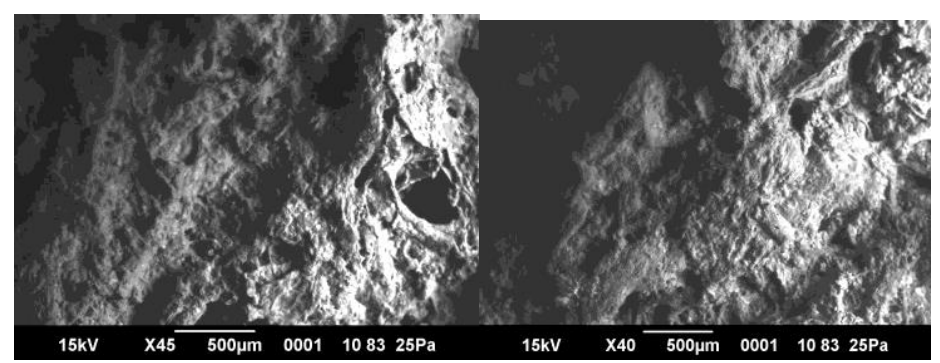

Figure 5. Microstructures of meat and bone paste after fermentation 
Thus, the meat and bone paste has high physical and chemical characteristics. As a result of the impact on the meat and bone paste of ascorbic acid and pepsin at a temperature of $30{ }^{\circ} \mathrm{C}$ for 4 hours, after fermentation was established absence of bone particles, which indicates the possibility of further use of meat and bone paste in the technology of meat products.

This research was funded by the Ministry of Agriculture of the Republic of Kazakhstan (BR10764970).

\section{REFERENCES}

1. Mitrofanova A.B., Vetrov V.S. Perspektivy poluchenija pishhevoj mineral'noj dobavki iz kostnogo syr'ja // Agropanorama. - 2001. - P.38-39 (in Russian)

2. Kakimov, A., Suychinov, A., Mayorov, A., Yessimbekov, Z., Okuskhanova, E., Kuderinova, N., Bakiyeva, A. Meat-bone paste as an ingredient for meat batter, effect on physicochemical properties and amino acid composition // Pakistan Journal of Nutrition. - 2017. - 16 (10), PP. 797-804.

3. Zhou Yong Dong, Meng Yao Li, Gang Tian, Tie Hua Zhang, Hui Ren, Siew Young Quek. Effects of ultrasonic pretreatment on the structure and functionality of chicken bone protein prepared by enzymatic method // Food Chemistry. - 2019. Vol. 299 - 125103. - P. 1-10.

4. Cao J. et al. Extraction and physicochemical characterization of pepsin soluble collagens from golden pompano (Trachinotus blochii) skin and bone //Journal of Aquatic Food Product Technology. - 2019. - T. 28. - №. 8. - P. 837-847.

5. Erwanto Y. et al. Isolation and characterization of collagen from local goat bone using pepsin hydrolysis //IOP Conference Series: Earth and Environmental Science. - IOP Publishing, 2020. - T. 492. - №. 1. - P. 012083.

6. Kuderinova N. A. Development of technology for the production and use of a food component from bone raw materials: dissertation on. Cand. Techn. Sci. degree.: 05.18.04. - Semey: Semey State University named after Shakarim. - 2004. - 231 p. (in Russian)

7. Chiquita P., Noer U., Ofier S. Y. Collagen from chemical and enzymatic hydrolysis as a bone graft in the periodontal regenerative therapy
AIP Conference Proceedings. - AIP Publishing LLC, 2020. - T. 2314. - №. 1. - P. 050016.

8. Voronina, T. Yu. Poluchenie gidrolizatov iz defektnogo zerna zlakov/T. Yu. Voronina, T. V. Ryazanova, S. M Voronin // Khimiya rastitel'nogo syr'ya. - 1998. - № 2. -P. 15-16 (in Russian)

9. Granatova, V. P. Teoriya i praktika polucheniya i primeneniya natural'nykh strukturoobrazovatelei / V. P. Granatova, A. A. Zaporozhskii, G. I. Kas'yanov // Izv. vuzov. Pishchevaya tekhnologiya. - 2007. - №2.- P. 5-8. (in Russian)

10. Chen, L., Chen, J., Ren, J., \& Zhao, M. Effects of ultrasound pretreatment on the enzymatic hydrolysis of soy protein isolates and on the emulsifying properties of hydrolysates // Journal of Agricultural \& Food Chemistry. - 2011. - 59(6), 2600; DOI: 10.1021/jf103771x

11. Korot'ko G. F. Zheludochnoe pishchevarenie. Krasnodar, 2007, - 256 p. (In Russian)

12. Pepsin: The role of pepsin in digestion Access mode: http://polyguanidines.ru/ a $\mathrm{a}_{\text {- guan }}$ idini\&pepsin\&2.htm. Application date 15.08.2021(in Russian)

13. Antonov V.K. Khimiya proteoliza. - M.: Nauka, 1991. - 504 p. (in Russian)

14. Uniacke-Lowe T., Fox P. F. Chymosin, pepsins and other aspartyl proteinases: Structures, functions, catalytic mechanism and milk-clotting properties //Cheese. - 2017. - P. 69-113.

15. Kakimov A., Kabdylzhar B., Yessimbekov Zh., Suychinov A., Baikadamova A. Identifying patterns in the effect exerted by a cooling process and the fine grinding modes on the qualitative indicators of a meat and bone paste //Eastern-European Journal of Enterprise Technologies- 2020. - №2/11(104). - P.6-12.

16. Antipova L. V., Glotova I. A., Rogov I. A. Metody issledovaniya myasa i myasoproduktov. M.: Kolos, 2001. - 376 p. (in Russian)

17. GOST 32224-2013. Myaso i myasoprodukty dlya detskogo pitaniya. Sposob opredeleniya razmera chastits kosti. - Vvedenie. 2015-07-01. - M.: Standartinform, 2014. - 6 p. (in Russian)

18. Suslova A. I., Bakhtairova V. I. Osnovnye ponyatiya biokhimii. Fermenty: uchebnoe posobie dlya inostrannykh studentov. - Irkutsk: ISMU, 2014. - 41 p. (in Russian) 